\title{
A SYSTEMATIC REVIEW OF TRADITIONAL USES BIOACTIVE PHYTOCONSTITUENTS OF GENUS EHRETIA
}

\author{
ABHA SHUKLA*, AMANPREET KAUR
}

\author{
Department of Chemistry, Gurukula Kangri Vishwavidyalaya, Haridwar - 249 404, Uttarakhand, India.
}

Email:amanpreet2225@gmail.com

Received: 07 February 2018, Revised and Accepted: 12 March 2018

\begin{abstract}
The plants of the genus Ehretia composed of about 150 species mainly distributed in tropical Asia, Africa, Australia, and North America. They have been used as traditional and folk medicines to treat various ailments in Japan, India, and China for a long time. Previous phytochemical screenings demonstrated that the Ehretia plants mainly contain fatty acids, phenolic acids, flavonoids, cyanogenetic glycosides, and benzoquinones and other constituents from different chemical classes. The pharmacological studies confirmed that the crude extracts or individual compounds from the genus showed antioxidant, anti-inflammatory, antibacterial, antiarthritic, antitubercular, and antiallergic activities, as well as anti-snake venom property. In this review, we presented a summary of the secondary metabolites isolated from different species of Ehretia based on the published literatures up to March 2017. In addition to the traditional medicinal use of Ehretia plants, we focused on the known biological activities of the plants and discussed them in detail here.
\end{abstract}

Keywords: Ehretia, Traditional and medicinal importance, Essential oil, Antiparasitic activity, Future prospects.

(C) 2018 The Authors. Published by Innovare Academic Sciences Pvt Ltd. This is an open access article under the CC BY license (http://creativecommons. org/licenses/by/4. 0/) DOI: http://dx.doi.org/10.22159/ajpcr.2018.v11i6.25178

\section{INTRODUCTION}

Ehretia genus has around 150 species belongs to the family Boraginaceae [1-3]. Many species are mainly distributed in tropical Asia, Africa, Australia, Europe, and Northern America [4-14]. All species of Ehretia are trees (Ehretia acuminata) and shrubs [15] (Ehretia rigida). The leaves, barks, roots, branches, fruits, and heartwoods are used as the traditional medicines in China, Japan, and India. Some species produce small fruits are visited by a broad variety of opportunistic avian frugivores, and some species could be a valuable supplementary feedstuff for ruminant livestock and wild animal due to its in vitro fermentation characteristics as well as low fiber [15-19]. In India, genus Ehretia is reported for many species such as Ehretia laevis Roxb., E. acuminata R.Br [20], and Ehretia microphylla [21,22]. These species are used in many herbal and traditional medicines in India and China because of their good response in many biological activities. Ehretia genus has reported the presence of phenolic acids, lignans, flavonoids, nitrile glycosides, quinonoids, steroids, triterpenoids, and pyrrolizidine alkaloid [23,24]. Many species of Ehretia genus are reported for antiinflammatory, antidiabetic, and antibacterial activity. Some important species of this genus are Ehretia longiflora, E. laevis, E. acuminata, E. microphylla, and Ehretia obtusifolia.

In an effort to provide the up-to-date information of the genus Ehretia, in previous, some chemical constituents and activities have published up to 2010 [25], and this article represents the results of an extensive investigation of the chemotaxonomy, secondary metabolites, biological activities, and pharmacological applications of this genus up to 2017, which would assist further researches and potential applications of the plants.

\section{TRADITIONAL AND MEDICINAL IMPORTANCE OF SOME SPECIES OF GENUS EHRETIA}

Different plants of genus Ehretia are widely used traditionally in many herbal and Chinese medicines from last few decades in China, India, and Japan [26,27] (Table 1).

\section{CHEMICAL CONSTITUENT PRESENT IN GENUS EHRETIA}

Species present under the genus Ehretia contains many phytoconstituents such as - phenolic acids, flavonoids, benzoquinones, cyanogenetic glycosides, fatty acids, and some other important compounds

Phenolic acids

Plants are potential sources of natural bioactive compounds such as secondary metabolites and antioxidants. Phenolic acids are the secondary metabolites and therapeutic agent present in medicinal plant. Phenolic compounds confer unique taste and health-promoting properties found in vegetables and fruits. The effect of dietary phenolics is currently of great interest due to their antioxidative and possible anticarcinogenic effect (Table 2).

\section{Flavonoids}

Flavonoids are the polyphenolic compounds among secondary metabolites in different parts of plants that possess a wide range of biological activities. They are present in fruits, vegetables, nuts, spices, and herbs and derived products such as wine, tea, and chocolate. The flavonoid class includes more than 6000 compounds as found in nature and comprises several subclasses including flavonols (e.g., quercetin, kaempferol, myricetin, and rhamnazin), flavones (e.g., apigenin, luteolin, and tangeretin), flavanones (e.g., hesperetin, naringenin, and eriodictyol), flavanols (e.g., catechins and epicatechins), anthocyanidins (e.g., cyanidin, delphinidin, and malvidin), and isoflavones (e.g., genistein, daidzein, and glycitein) (Table 3).

\section{Alkaloids}

Alkaloids are quite important secondary metabolites of plants. They are internal constituents of plants so-called biomolecules. Uses of alkaloids primarily mean their use in health care. They act as lifesaving drugs in various serious disorders such as heart failure, blood pressure, and cancer. Several alkaloids isolated from natural herbs exhibit antimetastasis and antiproliferation effects on various types of cancers such as vinblastine and camptothecin and have already been successfully developed into anticancer drugs. Lycorine, indicine n-oxide, alstonine, cocaine, quinine, and quinidine are some alkaloids present in plants (Table 4).

Fatty acids

Plants synthesize a huge variety of fatty acids although only a few are major and common phytoconstituents. Fatty acids are 
Table 1: Traditional uses of genus Ehretia

\begin{tabular}{|c|c|c|c|c|}
\hline Botanical name & Common name & Part used & Traditional use & References \\
\hline Ehretia acuminata R.Br. & Pudila, Nara, Koda & $\begin{array}{l}\text { 1. Leaves } \\
\text { 2. Bark } \\
\text { 3. Root }\end{array}$ & $\begin{array}{l}\text { 1. The extract of the leaves mixed with water } \\
\text { and taken orally once daily for } 2-3 \text { days to cure } \\
\text { acute dysentery } \\
\text { 2. Bark juice used in sores on tongue and fever }\end{array}$ & $\begin{array}{l}{[28]} \\
{[29]}\end{array}$ \\
\hline Ehretia laevis Roxb. & $\begin{array}{l}\text { Chamror (Punjab). Kuptaa, } \\
\text { Datarangi (Maharashtra) }\end{array}$ & $\begin{array}{l}\text { 1. Leaves } \\
\text { 2. Root } \\
\text { 3. Bark } \\
\text { 4. Fruit }\end{array}$ & $\begin{array}{l}\text { 1. Leaves juice is applied in ulcer, skin disease, } \\
\text { and headache } \\
\text { 2. Root used in venereal diseases } \\
\text { 3. Bark is used internally and as gargle in throat } \\
\text { infections, inner bark of E. laevis is used as food } \\
\text { 4. Fruit used in infections of urinary passages, } \\
\text { diseases of lungs and spleen }\end{array}$ & $\begin{array}{l}{[30]} \\
{[31]} \\
{[32]}\end{array}$ \\
\hline Ehretia microphylla Lam. & Pala. & $\begin{array}{l}\text { 1. Leaves } \\
\text { 2. Root }\end{array}$ & $\begin{array}{l}\text { 1. Dried leaves used in stomachic, decoction } \\
\text { of the leaves is used as cure for coughs and is } \\
\text { prescribed for the treatment of cyaniding with } \\
\text { bloody discharge and for dysentery } \\
\text { 2. Root in cachexia and syphilis; an antidote to } \\
\text { vegetable poisoning }\end{array}$ & {$[33]$} \\
\hline $\begin{array}{l}\text { Ehretia obtusifolia. } \\
\text { Hochst. ex A.DC }\end{array}$ & & $\begin{array}{l}\text { 1. Leaves } \\
\text { 2. Thin branches }\end{array}$ & 1. Decoction of leaves and bark in Malaria & {$[34]$} \\
\hline Ehretia cymosa & & $\begin{array}{l}\text { 1. Leaves } \\
\text { 2. Bark }\end{array}$ & $\begin{array}{l}\text { 1. Different parts of plant are used in diarrhea } \\
\text { 2. The extract of leaves used in Malaria } \\
\text { 3. Bark and leaves used in epilepsy }\end{array}$ & {$[35]$} \\
\hline Ehretia amoena & & $\begin{array}{l}\text { 1. Leaves } \\
\text { 2. Bark } \\
\text { 3. Root }\end{array}$ & 1. Plant works against trypanosomiasis & {$[36]$} \\
\hline
\end{tabular}

Table 2: Phenolic acids separated from genus Ehretia

\begin{tabular}{|c|c|c|c|}
\hline S. no & Phenolic acid & Species & References \\
\hline 1. & Buddlenol B & E. ovalifolia & [37] \\
\hline 2. & Caffeic acid & E. thyrsiflora & [38] \\
\hline 3. & Danshensu & E. thyrsiflora & [39] \\
\hline 4. & Cinnamic acid & E. thyrsiflora & [39] \\
\hline 5. & Ehletianol A & E. ovalifolia & {$[37]$} \\
\hline 6. & Ehletianol B & E. ovalifolia & [37] \\
\hline 7. & Ehletianol D & E. ovalifolia & [37] \\
\hline 9. & Caffeic anhydride & E. obtusifolia & [34] \\
\hline \multirow{2}{*}{10.} & Icariside E5 & E. ovalifolia & [37] \\
\hline & & E. thyrsiflora & [39] \\
\hline 11. & Lithospermic acid B & E. thyrsiflora & [39] \\
\hline 12. & Methyl 2-0-feruloyl-1a-0-vanillactate & E. obtusifolia & [34] \\
\hline \multirow[t]{2}{*}{13.} & Methyl rosmarinate & E. obtusifolia & [34] \\
\hline & & E. thyrsiflora & {$[38]$} \\
\hline \multirow{2}{*}{$\begin{array}{l}14 . \\
15 .\end{array}$} & p-hydroxybenzoic acid & E. thyrsiflora & {$[38]$} \\
\hline & & E. thyrsiflora & [39] \\
\hline 16. & Trans-4-hydroxycyclohexyl-2-0-p-coumaroyl- $\beta$-D-glucopyranoside & E. obtusifolia & {$[34]$} \\
\hline 17. & Ehletianol C & E. ovalifolia & [37] \\
\hline 18. & $\begin{array}{l}\text { 1-(4-hydroxy-3-methoxyphenyl)-2-\{2-methoxy-4-[1-(E) propen-3-ol]- } \\
\text { phenoxy\}-propane-3-diol (erythro) }\end{array}$ & E. ovalifolia & [37] \\
\hline 19. & 1-(4-hydroxy-3-methoxyphenyl)-2-\{2-methoxy-4-[1-(E) propen-3-ol]-phenoxy\}-propane-l, 3-diol (threo) & E. ovalifolia & [37] \\
\hline 20. & Trans-ferulic acid & E. thyrsiflora & [39] \\
\hline
\end{tabular}

E. ovalifolia: Ehretia ovalifolia, E. thyrsiflora: Ehretia thyrsiflora, E. obtusifolia: Ehretia obtusifolia

important dietetic sources of fuel for animals because, when metabolized, they yield large quantities of ATP(Adenosine triphosphate). Many types of cell can use either fatty acids or glucose for this purpose. Long-chain fatty acids are not capable to cross the blood-brain barrier and so cannot be used as fuel by the cells of the central nervous system (Table 5).

\section{Benzoquinones}

Quinones, a type of plant-derived secondary metabolites and benzoquinones, are widely distributed in the plant kingdom and mainly exist in higher plants, such as those from the Polygonaceaee, Rubiaceae,
Leguminosae, Rhamnaceae, Labiatae, and Boraginaceae families, among others. Moreover, a number of benzoquinones show significant biological activities such as anticancer and antibacterial activities (Table 6).

\section{Glycosides}

In the chemical constituents occur in a glycoside are important, secondary metabolites. However, biological activities of glycosides are, in many cases, susceptible to the nature of sugar moieties. They are an essential resource of natural medicine, health food, cosmetics, and food supplements (Table 7). 
Table 3: Flavonoids separated from from genus Ehretia

\begin{tabular}{lll}
\hline S. no & Flavonoids & Species \\
\hline 21. & Apigenin & E. ovalifolia \\
22. & Hyperoside & E. thyrsiflora \\
23. & Luteolin & E. ovalifolia \\
24. & Kaempferol-3-O- $\alpha-D$-arabinoside & E. thyrsiflora \\
25. & Kaempferol-3-O- $\beta-D$-galactopyranoside & E. thyrsiflora \\
26. & Kaempferol-3-O- $\beta$ - $D$-glucopyranoside & E. thyrsiflora \\
27. & Kaempferol-3-O-arabinosylgalactoside & E. thyrsiflora \\
28. & Kaempferol & E. thyrsiflora \\
29. & Quercetin & E. thyrsiflora \\
30. & Quercetin-3-O- $\alpha-D$ arabinoside & E. thyrsiflora \\
31. & Quercetin-3-O- $\beta-D$-glucopyranoside & E. thyrsiflora \\
32. & Quercetin-3-O-arabinosylgalactoside & E. thyrsiflora \\
33. & Ovalifolin & {$[39]$} \\
\hline
\end{tabular}

E. ovalifolia: Ehretia ovalifolia, E. thyrsiflora: Ehretia thyrsiflora, E. obtusifolia: Ehretia obtusifolia

Table 4: Alkaloids separated from from genus Ehretia

\begin{tabular}{lll}
\hline S. no & Alkaloids & Species \\
\hline 34. & Ehretinine & E. aspera \\
35. & Allantoin & E. thyrsiflora \\
\hline
\end{tabular}

E. aspera: Ehretia aspera, E. thyrsiflora: Ehretia thyrsiflora

Table 5: Fatty acids separated from from genus Ehretia

\begin{tabular}{|c|c|c|c|}
\hline S. no & Fatty acid & Species & References \\
\hline 36. & Araneosol & E. ovalifolia & [40] \\
\hline 37. & Di (octadecyl) phthalate & E. thyrsiflora & [42] \\
\hline 38. & Tetradecanoic acid 2, 3-dihydroxypropyl ester & E. thyrsiflora & [42] \\
\hline 39. & $(10 E, 12 Z, 15 Z)-9$-hydroxy-10,12,15-octadecatrienoic acid methyl ester & E. dicksonii & [43] \\
\hline 40. & $(9 Z, 11 E)-13$-oxo-9, 11-octadecadienoic acid & E. dicksonii & [43] \\
\hline 41. & $(9 Z, 11 E)-13$-hydroxy-9, 11-octadecadienoic acid & E. dicksonii & [43] \\
\hline 42. & 2-methoxylbenzoic acid octyl ester & E. thyrsiflora & [42] \\
\hline
\end{tabular}

E. ovalifolia: Ehretia ovalifolia, E. thyrsiflora: Ehretia thyrsiflora, E. dicksonii: Ehretia dicksonii

Table 6: Benzoquinones separated from genus Ehretia

\begin{tabular}{llll}
\hline S. no & Benzoquinone & Species & References \\
\hline 43. & Cyclomicrophyllone & E. microphylla & {$[33]$} \\
44. & Dehydromicrophyllone & E. microphylla & {$[33]$} \\
45. & Ehretianone & E. buxifolia & {$[44]$} \\
46. & Allomicrophyllone & E. microphylla & {$[33]$} \\
47. & Hydroxymicrophyllone & E. microphylla & {$[33]$} \\
48. & Microphyllone & E. microphylla & {$[33]$} \\
49. & 1,4-naphthoquinone & E. laevis & {$[45]$} \\
& lewisone & & \\
50. & Ehretiquinone & E. longiflora & {$[47]$}
\end{tabular}

E. microphylla: Ehretia microphylla, E. buxifolia: Ehretia buxifolia,

E. laevis: Ehretia laevis, E. longiflora: Ehretia longiflora

Table 7: Glycosides separated from genus Ehretia

\begin{tabular}{llll}
\hline S. no & Glycoside & Species & References \\
\hline 51. & Simmondsin & E. philippinensis & {$[48]$} \\
52. & Ehretioside B & E.philippinensis & {$[48]$} \\
53. & Polyalcohol & E. philippinensis & {$[48]$} \\
54. & Ehretioside Al & E. philippinensis & {$[48]$} \\
55. & Ehretioside $\mathrm{A}_{2}$ & E.philippinensis & {$[48]$} \\
56. & Ehretioside $\mathrm{A}_{3}$ & E. philippinensis & {$[48]$} \\
\hline
\end{tabular}

E. philippinensis: Ehretia philippinensis
Table 8: Some other constituents separated from genus Ehretia

\begin{tabular}{llll}
\hline S. no & Compound & Species & References \\
\hline 57. & Bauerenol & E. laevis & {$[49]$} \\
58. & Betulin & E. laevis & {$[49]$} \\
59. & Bauerenol acetate & E. laevis & {$[49]$} \\
60. & Betulinic acid & E. laevis & {$[49]$} \\
61. & Lupeol & E. laevis & {$[49]$} \\
62. & $\alpha$-amyrin & E. laevis & {$[49]$} \\
63. & -sitosterol & E. laevis & {$[49]$} \\
64. & Daucosterol & E. thyrsiflora & {$[42]$} \\
65. & Stigmasterol & E. buxifolia & {$[44]$} \\
66. & $\alpha$-spinasterol & E. buxifolia & {$[44]$} \\
67. & Campesterol & E. buxifolia & {$[44]$} \\
68. & Stigmastanol & E. buxifolia & {$[44]$} \\
69. & Ehretiolide & E. longiflora & {$[47]$} \\
70. & Ehreticoumarin & E. longiflora & {$[47]$} \\
71. & Ehretilactone A & E. longiflora & {$[47]$} \\
72. & Ehretilactone B & E. longiflora & {$[47]$} \\
73. & Ehretiamide & E. longiflora & {$[47]$} \\
74. & Ehretine & E. longiflora & {$[47]$} \\
75. & Ehretiate & E. longiflora & {$[47]$} \\
\hline
\end{tabular}

E. laevis: Ehretia laevis, E. thyrsiflora: Ehretia thyrsiflora, E. buxifolia: Ehretia buxifolia, E. longiflora: Ehretia longiflora

\section{OTHER IMPORTANT CONSTITUENTS EXTRACT FROM GENUS EHRETIA}

Many other important constituents are also reported from different parts such as leaves, bark, fruit, and root of plants of Ehretia genus (Table 8). 
CHEMICAL STRUCTURE OF COMPOUND PRESENT IN EHRETIA GENUS (FIGS. 1-75)
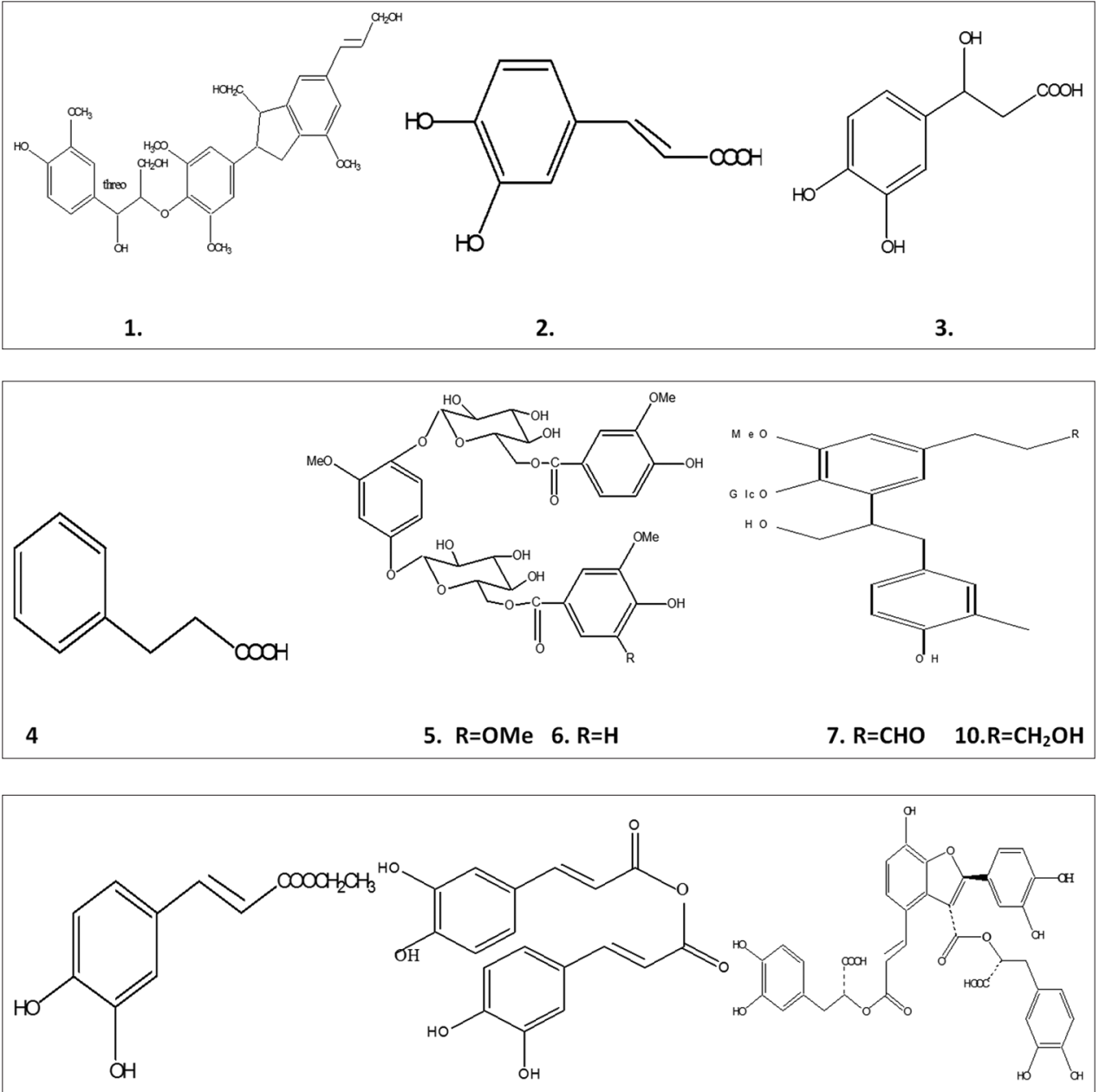

8.

9.

11.
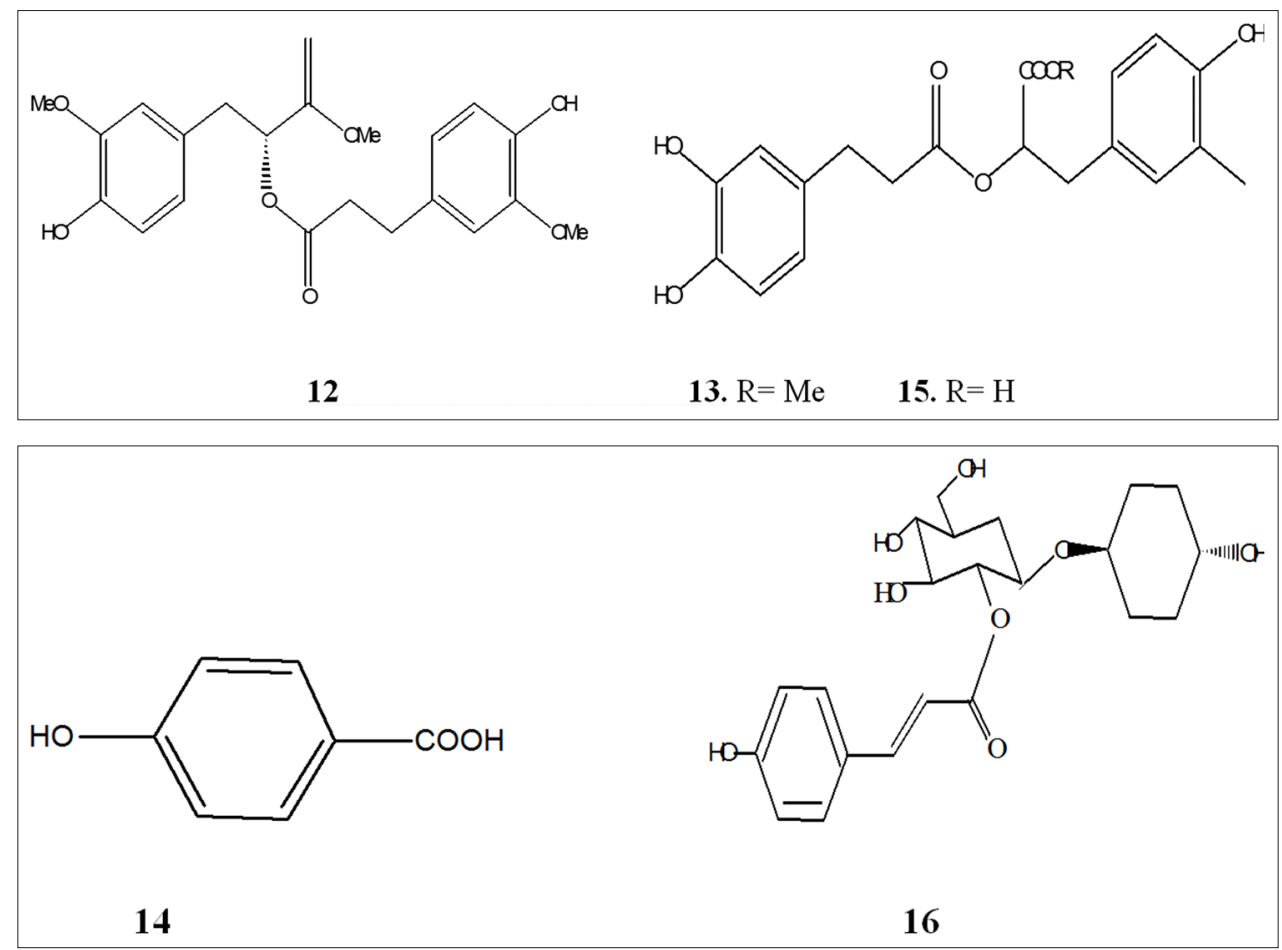

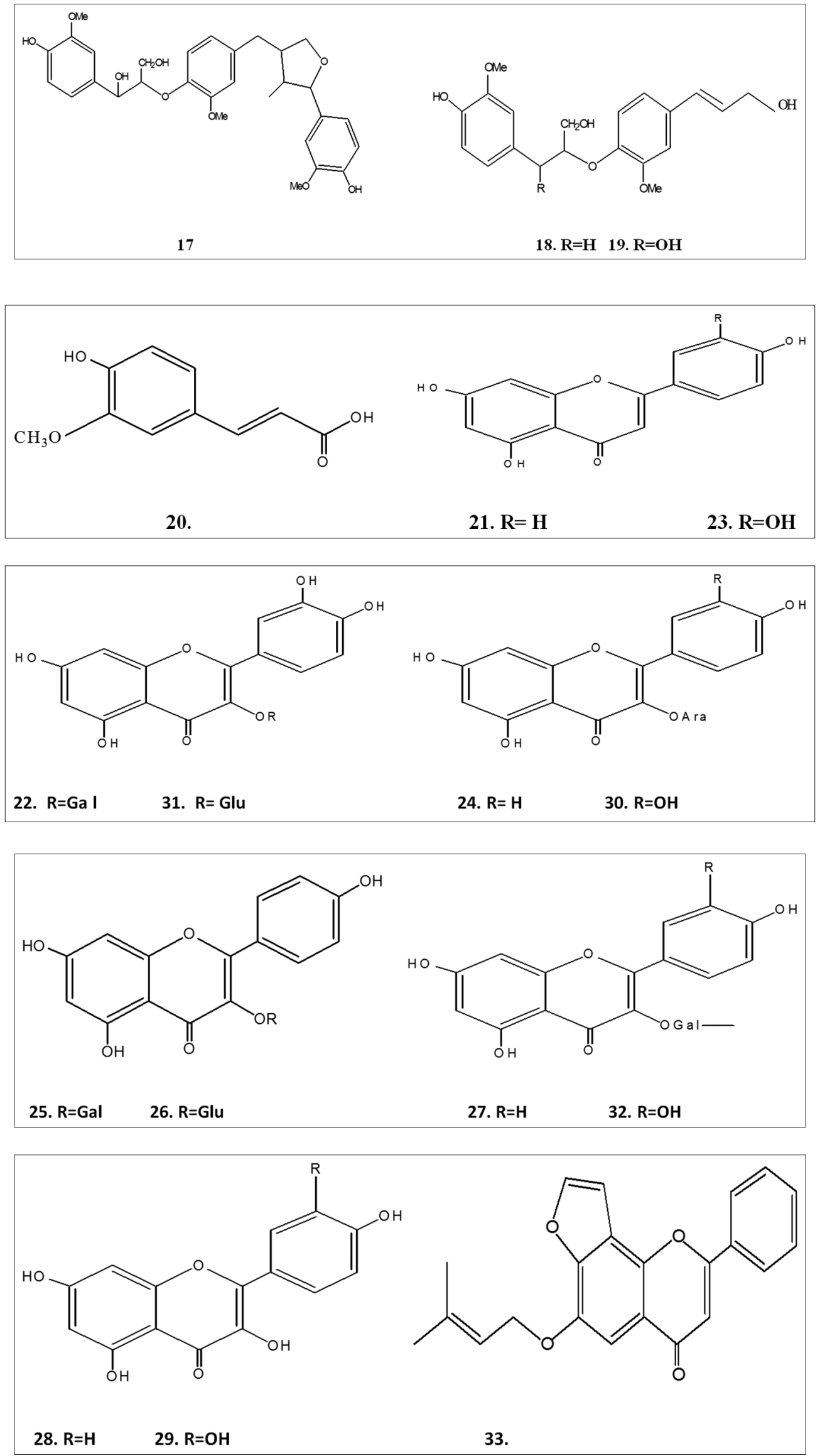

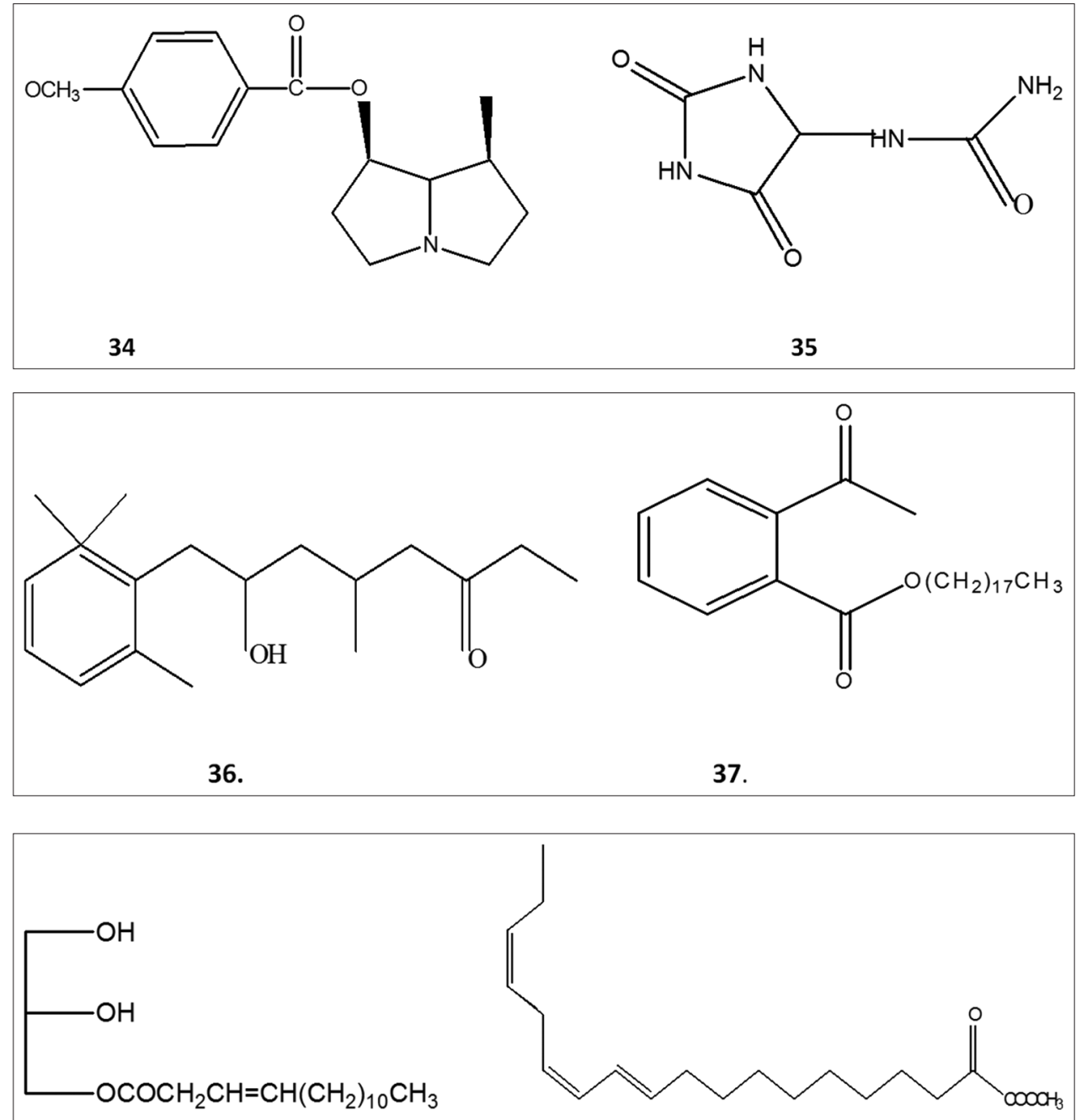

38.

39.
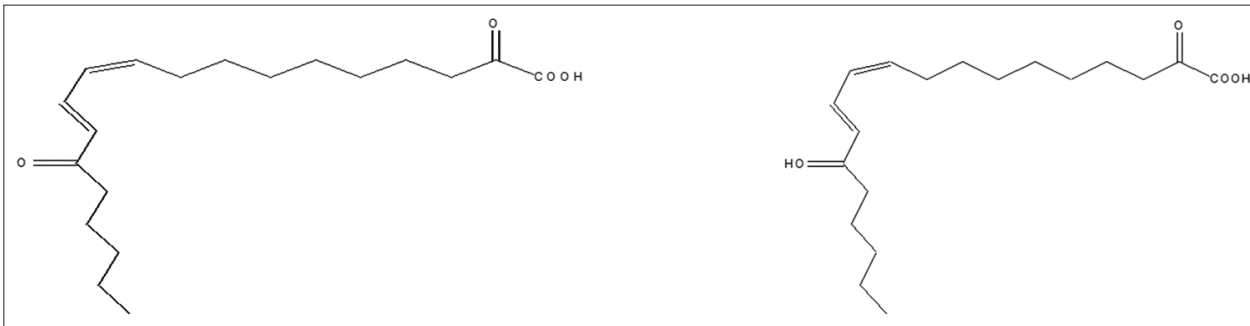

40.

41
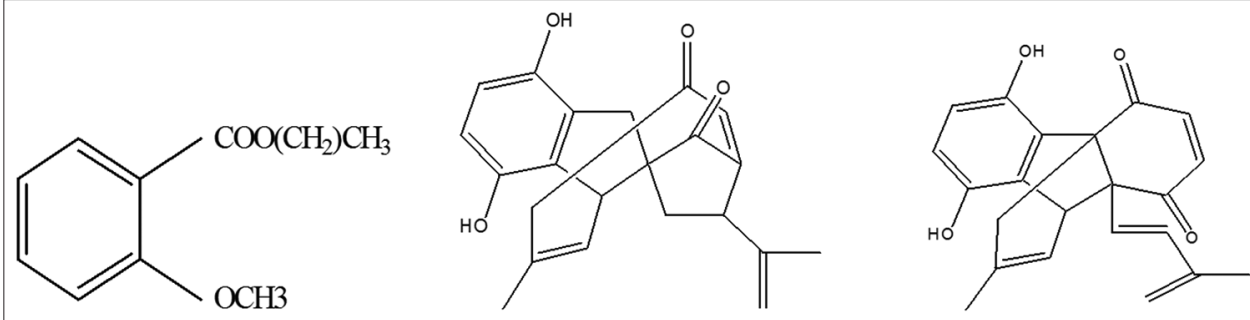

42.

43.

44. 

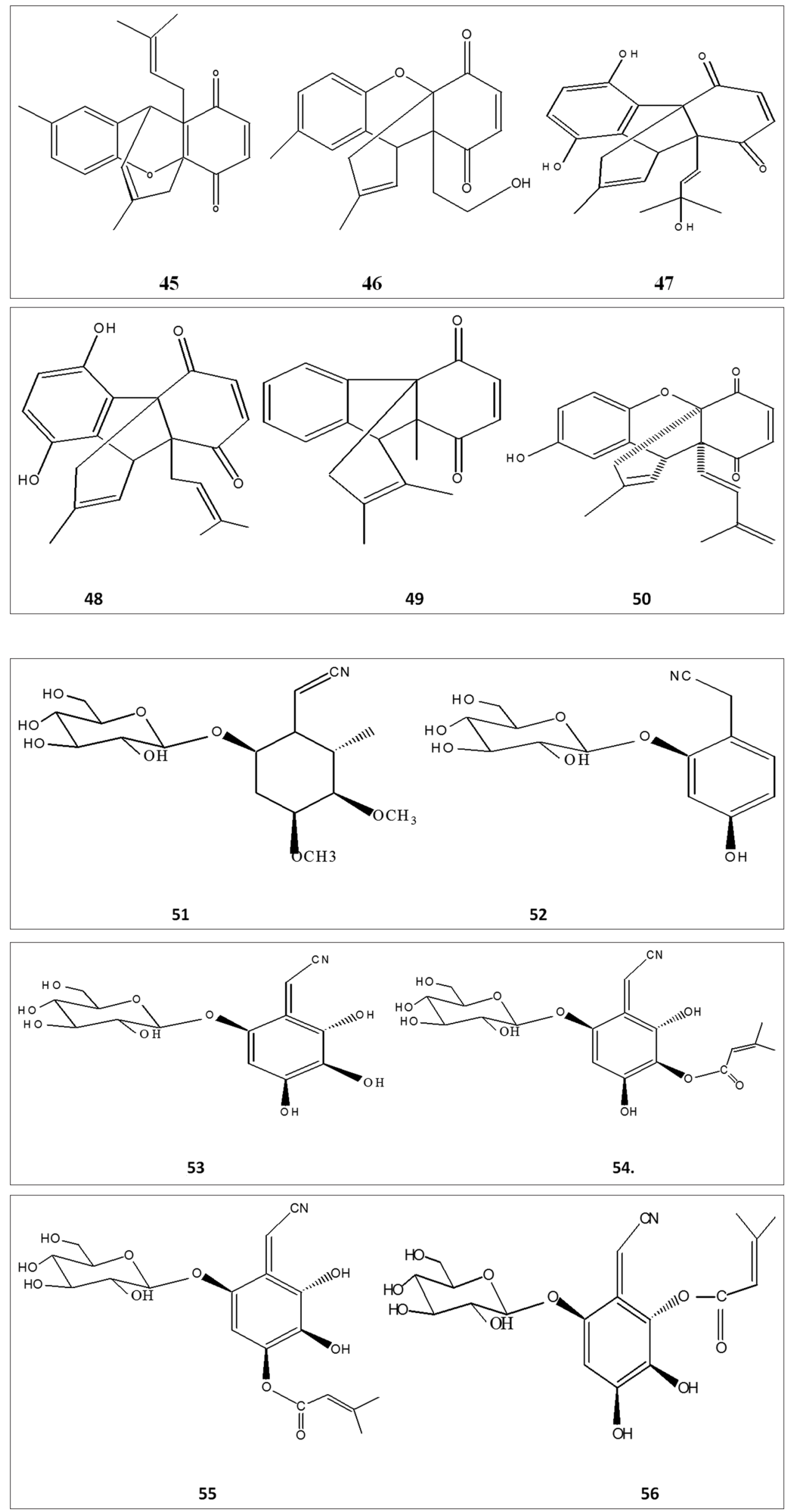

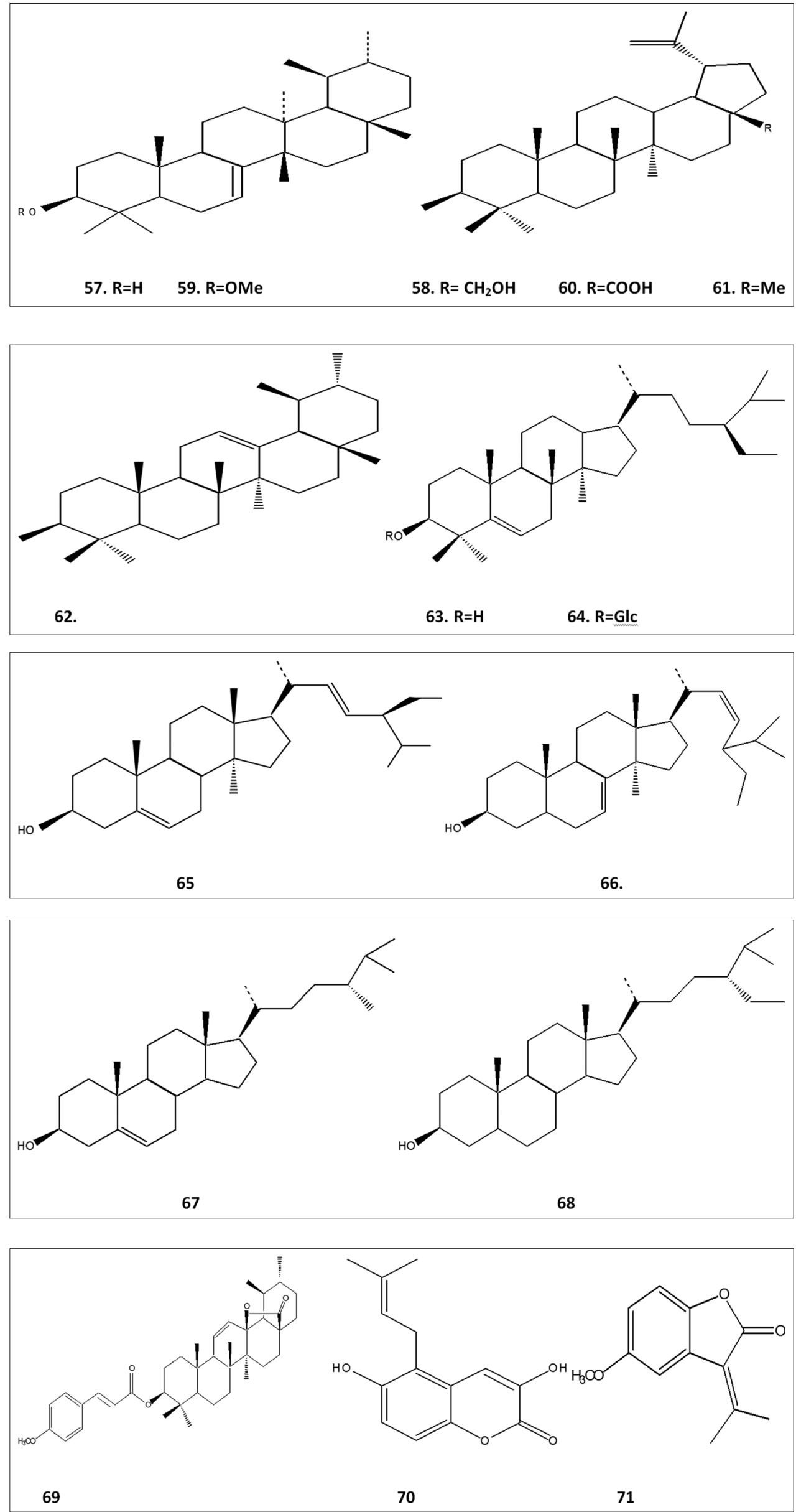

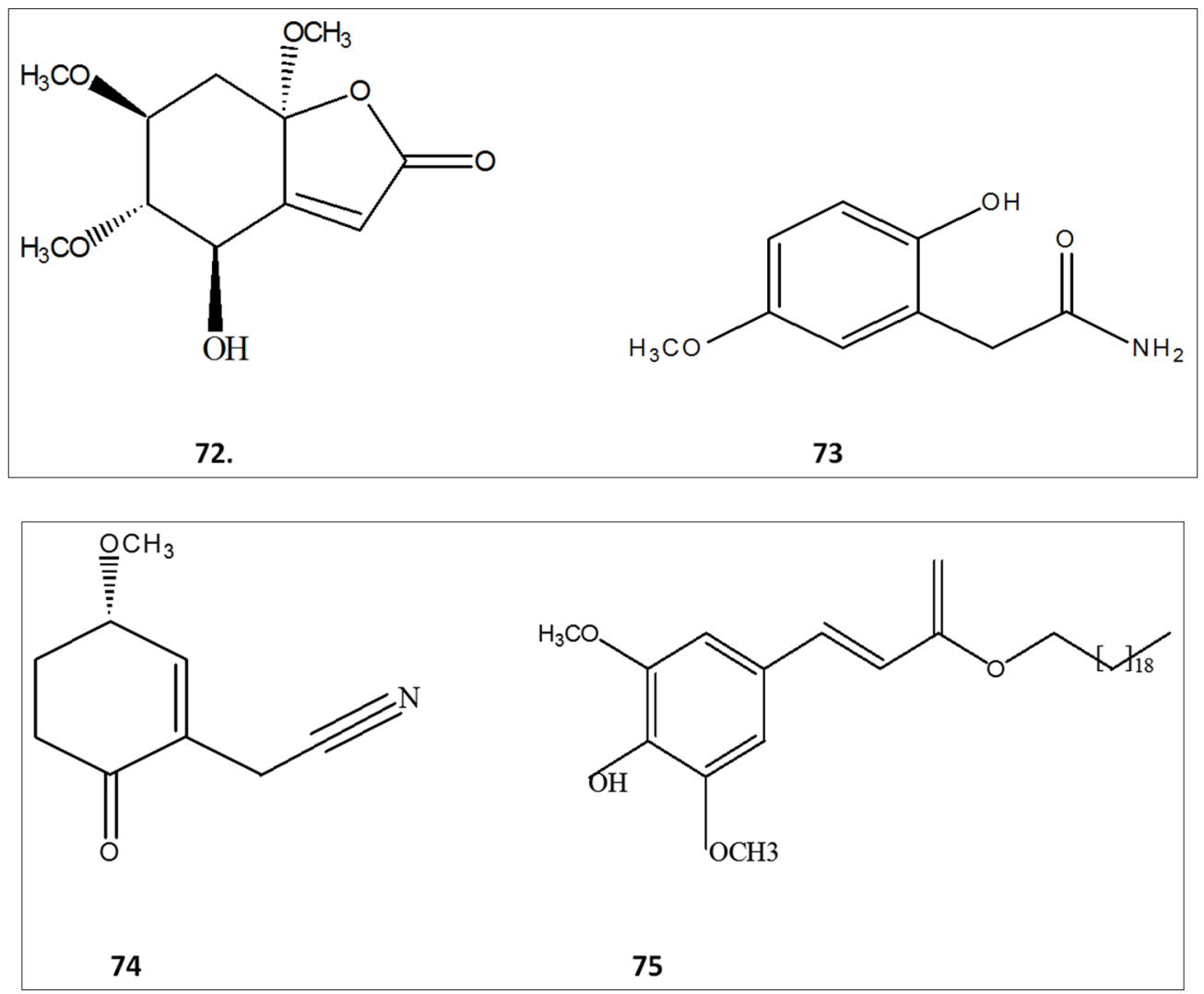

\section{Essential oil}

Essential oil extracted from leaves of Ehretia cymosa by hydrodistillation. Some chemical constituents separated by comparison of their mass spectra with NIST from essential oil which mainly comprised sesquiterpene hydrocarbon compounds.
The other classes of compounds identified in these essential oils were monoterpenes, alcohols, phenylpropanoids, esters, and fatty acids. In addition, some of the studied volatile oils have exhibited biological activities such as antimicrobial, phytotoxicity, insecticidal, and cytotoxicity (Table 9).

\section{SOME SPECIES OF GENUS EHRETIA}

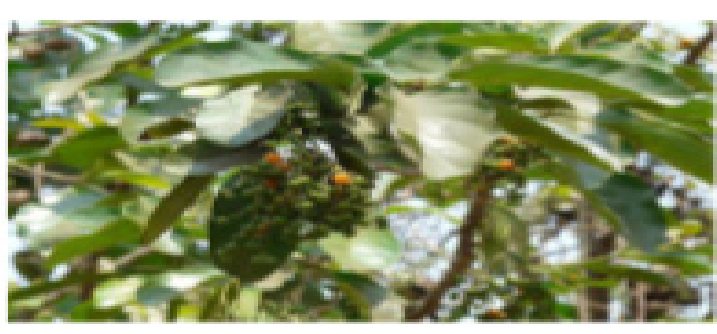

\section{Ehretia leavis}

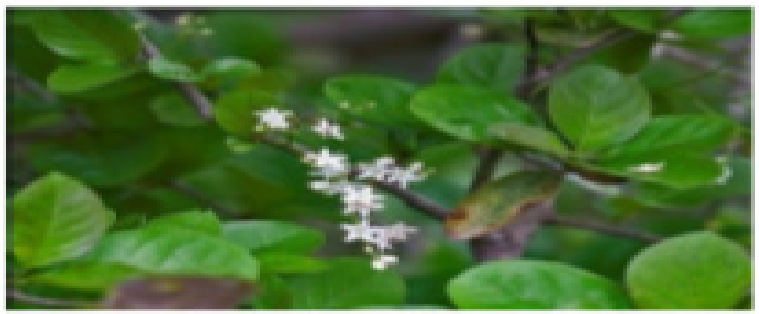

Ehretia aspena

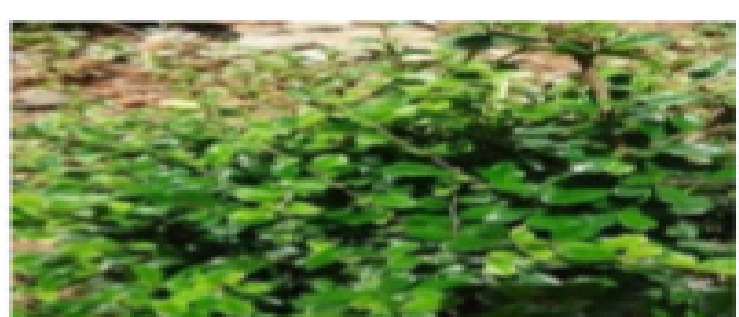

Ehretia microphylla

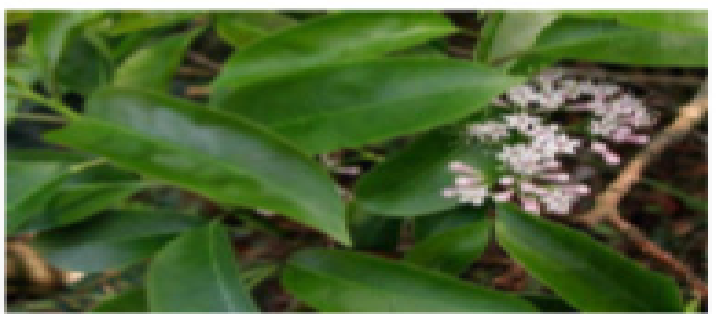

Ehretia longiflora 


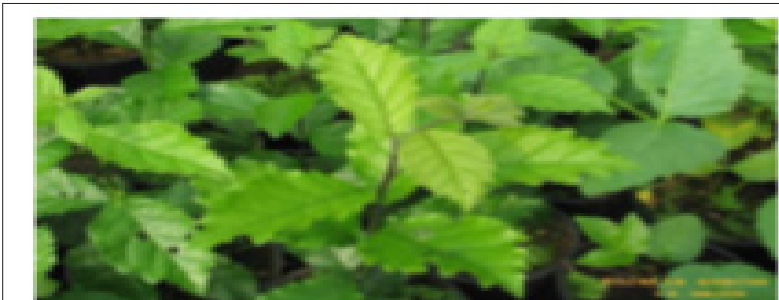

Ehretta anacua

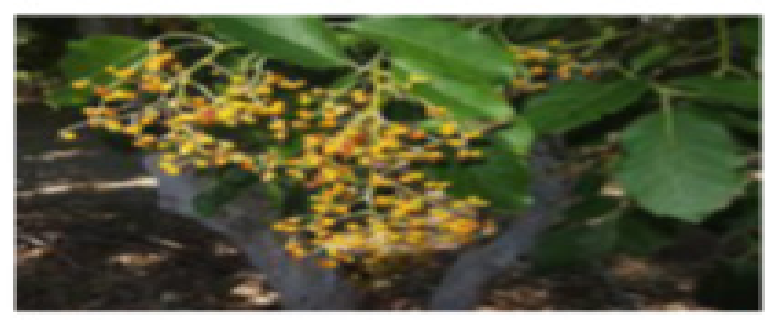

Ehrretia acuminata

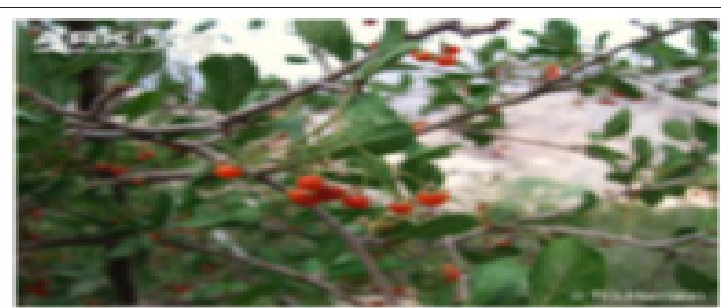

Ehretia obrusifolia

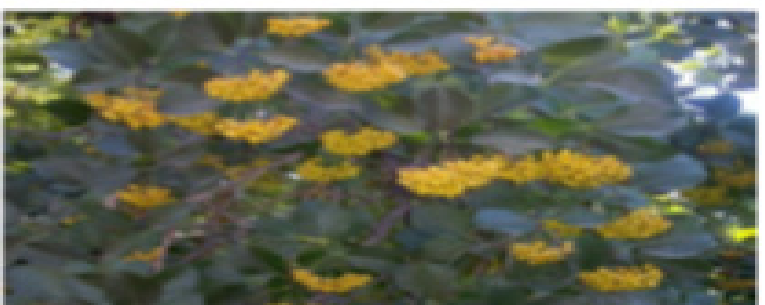

Ehretia diclesonii

\section{BIOLOGICAL ACTIVITIES OF DIFFERENT SPECIES OF GENUS EHRETIA}

Many species of genus Ehretia show different biological activities such as antioxidant, antibacterial, anti-inflammatory, antiarthritic, and antisnake venom activities.

\section{Antioxidant activity}

Many compounds, naturally occurring from plant sources, have been identified as free radical or active oxygen scavengers. Recently, interest has increased substantially in finding naturally occurring antioxidant for use in foods or medicinal materials to replace synthetic antioxidants, which are being restricted due to their side effects such as carcinogenicity. Natural antioxidants can protect the human body from free radicals and retard the progress of many chronic diseases as well as decelerate lipid oxidative rancidity in foods. In Ehretia serrata, 1-butanolic and chloroform fractions of leaves and ethyl acetate fraction of fruits showed appreciable results against free radical. 12 compounds including six phenolic acids and six flavonoids, rosmarinic acid, cinnamic acid, icariside E5, ferulic acid, $\alpha$-hydroxydihydrocaffeic acid, lithospermic acid B, isoquercitrin, hyperoside, trifolin, astragalin, kaempferol 3-0-arabinosylgalactoside, and quercetin 3-0-arabinosylgalactoside were first isolated from Ehretia thyrsiflora and have a significant response of antioxidant (Table 10).

\section{Anti-inflammatory activity}

The inflammatory process may be outline a sequence of events that occur in response to noxious stimuli, infection, or trauma. The classic signs of inflammation are redness, heat, swelling, pain, and loss of function. The issue of inflammation that underlines these manifestations are induced and regulated by a large number of chemical mediators including eicosanoids, kinins, complement proteins, histamine, and monokines (Table 11).

\section{Antiallergic activity}

Allergic disorders such as rhinitis, sinusitis, atopic dermatitis, asthma, pollenosis, and food allergy are the most common cause of human disease. There are a number of pharmacological agents available for the treatment of allergic conditions such as asthma and allergy rhinitis, and we also focus antiallergic activity as an essential step to the development of effective antiallergic agent. Some species of Ehretia genus have compounds such as dimeric prenylbenzoquinones, nitrile glucosides, and rosmarinic acid show antiallergic effect (Table 12).

\section{Anti-bacterial activity}

All extracts of E. laevis leaves (methanol, chloroform, and aqueous solvent) have revealed excellent antibacterial activity. When compared to methanol, chloroform, and aqueous methanolic extract showed the high antibacterial activity on Gram-positive and Gram-negative bacteria, and aqueous extracts show the high antibacterial activity on Gram-negative than Gram-positive. Some other species also show positive respond against antibacterial activity (Table 13).

\section{Antitubercular activity}

In human being, tuberculosis is a contagious infectious disease primarily caused by Mycobacterium tuberculosis. Although regimens exist for treating tuberculosis, they are far from ideal. Development of efficient strategies for the treatment of human tuberculosis has posed a challenge, considering the increase in infections associated with the human immunodeficiency virus and immunocompromised patients. Phytoconstituents have been used in traditional treatment of many diseases; however, careful investigation of these constituents has not been undertaken with respect to treatments of tuberculosis. Two compounds ehretiolide and prenylhydroquinone have extracted from root of Ehretia longiflora are responsible for antitubercular activity (Table 14).

\section{Anti-snake venom activity}

Snakebite is an important cause of morbidity and mortality and is one of the major health problems in India and other Asian countries. Ehretia buxifolia claimed to be useful in treating snake poison. The present study evaluated the potential antivenom effect Ehretia genus. A compound ehretianone has isolated from $\mathrm{MeOH}$ extract from E. buxifolia is responsible for anti-snake venom activity (Table 15).

\section{Antiarthritic activity}

Arthritis is an inflammatory disorder involving damage of joints. There are over a hundred different forms of arthritis, of which rheumatoid arthritis, osteoarthritis, and psoriatic arthritis are the most common. The treatment of any systemic disorder with allopathic drugs causes moderate-to-severe adverse effect that could cause death. Hence, alternative systems of medicine are being explored to treat diseases. E. laevis treatment supports antiarthritic activity. Of the three parts such as stem, leaf, and bark and fruit employed, the leaf extract was the most effective. This antiarthritic respond may be due to the presence of active constituents such as hexadecanoic acid (palmitic acid), oleanenic acid, and other fixed oils (Table 16). 
Antitrypanosomal and antiprotozoal activity

Sleeping sickness, leishmaniasis, Chagas disease, and malaria are infectious diseases caused by unicellular eukaryotic parasites "protozoans." The available drugs for the treatment of trypanosomiasis and protozoans are old, expensive, and less effective, associated with severe adverse reactions and face the problem of drug resistance. This situation underlines the urgent need for the development of new safe, cheap, and effective drugs for the treatment of parasitic disease. The search for new antitrypanosomal and antiprotozoal agents in this study is based on ethnomedicine. E. amoena show weak antitrypanosomal potential with ethanol extract of leaves, bark, and root. E. acuminata show antiprotozoal activity with methanol extract of leaves (Table 17).

\section{Antidiabetic activity}

Diabetes mellitus, one of the fastest-growing health problems, is concerned about the use of antihyperglycemic drugs because of undesirable pathological conditions, for example, the adverse effect of metformin is gastrointestinal discomfort, pioglitazone with bladder cancer and heart failure, and sulfonylureas with hypoglycemia and weight gain. There are the ethnobotanical studies of medicinal plants used in the treatment of diabetes mellitus in many countries. A lot of genus have already reported for effective respond of antidiabetic

Table 9: Compound separated from essential oil

\begin{tabular}{lll}
\hline S. no & Compound & References \\
\hline 1. & Linalool & {$[35]$} \\
2. & trans-Sesquisabinene hydrate & {$[40]$} \\
3. & Methyl salicylate & {$[40]$} \\
4. & O-tert-Butylphenol & {$[40]$} \\
5. & $\beta$ Ylangene & {$[40]$} \\
6. & $\beta$-Damascenone & {$[40]$} \\
7. & $\beta$-Cedrene & {$[40]$} \\
8. & $\beta$-Caryophyllene & {$[40]$} \\
9. & Trans- $\alpha$-Bergamotene & {$[40]$} \\
10. & Isocaryophyllene & {$[40]$} \\
11. & ar-Curcumene & {$[40]$} \\
12. & $\beta$-Bisabolene & {$[40]$} \\
13. & Oxygenated monoterpenes & {$[40]$} \\
14. & Sesquiterpene hydrocarbons & {$[40]$} \\
\hline
\end{tabular}

Table 10: Antioxidant activity of genus Ehretia

\begin{tabular}{llll}
\hline S. no & Species & Part used & References \\
\hline 1. & Ehretia thyrsiflora & Leaves & {$[50]$} \\
2. & Ehretia laevis Roxb. & Leaves & {$[51]$} \\
& & & {$[52]$} \\
3. & Ehretia serrata & Leaves and fruit & {$[53]$} \\
4. & Ehretia laevis Roxb. & Fruit & {$[54]$} \\
5. & Ehretia tinifolia & Fruit & {$[55]$} \\
6. & Ehretia microphylla & Aerial part & {$[56]$} \\
\hline
\end{tabular}

Table 11: Anti-inflammatory activity of genus Ehretia

\begin{tabular}{llll}
\hline S. no & Species & Part used & References \\
\hline 1. & E. dicksonii & Leaves & {$[43]$} \\
2. & E. obtusifolia & Leaves & {$[34]$} \\
3. & E. laevis Roxb. & Leaves & {$[57]$} \\
4. & E. longiflora & Root & {$[47]$} \\
\hline
\end{tabular}

E. dicksonii: Ehretia dicksonii, E. obtusifolia: Ehretia obtusifolia, E. laevis: Ehretia laevis, E. longiflora: Ehretia longiflora potential, but a few species of genus Ehretia are reported for antidiabetic activity yet. A species of E. laevis shows antidiabetic potential using multiwalled carbon nanotubes paste electrode in electrochemical measurement (Table 18)

\section{Cardiotonic activity}

Carmona retusa (E. microphylla) has a high potential infighting the growth and multiplication of cancer cells. However, there are no scientific data on the use of this plant on cardiotonic activity. Hence, this study was carried out to evaluate the effect of aqueous extract of various aerial parts of $C$. retusa on isolated frog's heart. The activity of the aqueous extract was found to be effective (Table 19).

\section{CONCLUSION AND FUTURE PROSPECTS}

The genus Ehretia contains abundant ingredients displaying extensive biological and pharmacological functions such as anti-snake venom, antiarthritic, antitrypanosomal, and antiprotozoal activity, and antiallergic activities. Despite that many Ehretia species have been used as the traditional medicines in Australia, North America, and Asian countries for long time, and numerous studies on chemistry and pharmacology have been conducted, the authors propose herein a few opinions with an attempt to shed light on the related investigations on Ehretia in future.

Foremost, Ehretia is a relatively vast genus, and there are considerable differences in their major secondary metabolites, these molecules were intensively described from E. longiflora, E. laevis, E. microphylla, E. obtusifolia, E. thyrsiflora, E. buxifolia, E. philippinensis, E. dicksonii, and E. ovalifolia, while no reports were found for other investigated species E. alba, E. angolensis, E. bakeri, E. coerulea, E. dichotoma, E. dolichandra, E. exsoluta, E. hainanensis, E. javanica, E. latifolia, and E. papuana. There are nine species found in South Africa E. coerulea, E. amoena, E. obtusifolia, E. namibiensis subsp. kaokoensis, E. namibiensis subsp. namibiensis, E. alba, E. rigida subsp. rigida, E. rigida subsp. silvatica, and E. rigida subsp. nervifolia. Recently, a new species of Ehretia retroserrata is reported in China [67].

Second, great efforts were devoted to explore the study of E. microphylla which indicate great potential of antibacterial and a recent research has done in India which shows Ehretia microphylla helps in treating irregular ovulation disorders and promotes fertility in female [68]. In Bangladesh, E. microphylla used in traditional medicinal treatment of various forms of cancer, and it is expected that scientific studies on this plants shall lead to discovery of novel anticancer compounds $[66,69,70]$. E. microphylla used widely in the traditional Philippine medicine and considered most promising for large-scale culture. Advice is given on vegetative propagation culture, harvesting, and storage (where appropriate), based on the results of preliminary trials [71].

E. laevis used as masticatories by the ethnic communities in India [72]. Unexplored wound healing property has shown by E. laevis. The best part is its leaves are effective, and hence, plenty of material is available without requirement of uprooting of plant [73]. Many researches have done by Indian scientists to improve the germination of multipurpose trees like E. laevis [74]. Molecular study has also done on some species to better understand the properties of genus Ehretia [75]. Recently, a research has done on Ehretia tinifolia which show positive response against diabetic complications, atherosclerosis, and cardiovascular diseases [76].

These properties have created a sense of conservation reservation and cultivation of the plant. The treatment is also very economic as only

Table 12: Antiallergic activity of genus Ehretia

\begin{tabular}{llll}
\hline S. no & Species & Compound & References \\
\hline 1. & Ehretia philippinensis & Nitrile glucosides, rosmarinic acid, methyl rosmarinate & {$[48]$} \\
2. & Ehretia microphylla & Rosmarinic acid & {$[58]$} \\
\hline
\end{tabular}


Table 13: Anti-bacterial activity of genus Ehretia

\begin{tabular}{llll}
\hline S. no & Species & Part used & References \\
\hline 1. & Ehretia laevis Roxb. & Leaves & {$[57,59]$} \\
2. & Ehretia abyssinica r.br. Ex fresen & Leaves & {$[60]$} \\
3. & Ehretia microphylla & Leaves & {$[61]$} \\
\hline
\end{tabular}

Table 14: Antitubercular activity of genus Ehretia

\begin{tabular}{llll}
\hline S. no & Species & Part used & Reference \\
\hline 1. & E. longiflora & Root & {$[47]$} \\
\hline E. longiflora: Ehretia longiflora & &
\end{tabular}

Table 15: Anti-snake venom activity of genus Ehretia

\begin{tabular}{llll}
\hline S. no & Species & Part used & Reference \\
\hline 1. & E. buxifolia & Root, Bark & {$[44]$} \\
\hline
\end{tabular}

E. buxifolia: Ehretia buxifolia

Table 16: Antiarthritic activity of genus Ehretia

\begin{tabular}{llll}
\hline S. no & Species & Part used & Reference \\
\hline 1. & E. laevis Roxb. & Leaves & {$[62]$} \\
\hline
\end{tabular}

E. laevis: Ehretia laevis

Table 17: Antitrypanosomal and antiprotozoal activity of genus Ehretia

\begin{tabular}{llll}
\hline S. no & Species & Part used & References \\
\hline 1. & E. amoena & Leaves, root, bark & {$[36,63]$} \\
2. & E. acuminata & Leaves & {$[64]$} \\
\hline
\end{tabular}

E. amoena: Ehretia amoena, E. acuminata: Ehretia acuminata

Table 18: Antidiabetic activity of genus Ehretia

\begin{tabular}{llll}
\hline S. no & Species & Part used & Reference \\
\hline 1. & E. laevis & Leaves & {$[65]$} \\
\hline E. laevis: Ehretia laevis & &
\end{tabular}

Table 19: Cardiotonic activity of genus Ehretia

\begin{tabular}{llll}
\hline S. no & Species & Part used & Reference \\
\hline 1. & E. microphylla & Aerial part & {$[66]$} \\
\hline E. microphylla: & Ehretia microphylla & &
\end{tabular}

paste is to be prepared in aseptic condition. The study revealed that no antibiotic work required, and hence, the immunological study of patient was not hampered; similarly, there were huge savings in the medical expenditure which is very important in developing country like India [77]. This research has confirmed the antimicrobial potentials of E. laevis supporting its application as a preventive remedy for various microbial diseases of hard tissues in the oral cavity [59].

Plants of this genus as a native to India can become a great source of income for the nation if this potential for highly pharmacological use exploited by the researchers and industries by undertaking further research to corroborate earlier studies.

\section{AUTHOR'S CONTRIBUTIONS}

Amanpreet Kaur: Conceptualization of paper, compilation full literature, and wrote manuscript. Abha Shukla: Reviewing and checking of the manuscript and contributed in enhancing the standard of the manuscript.

\section{CONFLICTS OF INTEREST}

The authors declare that they have no conflicts of interest.

\section{REFERENCES}

1. Gottschling M, Hilger HH. Characterisation of a novel fruit type found in Ehretia (Ehretiaceae, Boraginales). Blumea 2004a;49:145-53.

2. Sahay SK. On the Pollen Morphology of Ehretiaceae with Reference to Taxonomy. IV Int. Palynol. Conf. 1979. p. 471-9.

3. Rabaey D, Lens F, Smets E Jansen S. The phylogenetic significance of vestured pits in Boraginaceae. Int Assoc Plant Taxonomy 2010;59:510-6.

4. Sultana A, Hussain MS, Rathore DK. Diversity of tree vegetation of Rajasthan, India. Trop Ecol 2014;55:403-10.

5. Mandal G, Joshi SP. Analysis of vegetation dynamics and phytodiversity from three dry deciduous forests of Doon Valley, Western Himalaya, India. J Asia Pac Biodivers 2014a;7:292-304.

6. Gottschling M, Hilger HH. The systematic position of Ehretia cortesia nom. nov. (-Cortesia cuneifolia: Ehretiaceae, Boraginales) inferred from molecular and morphological data. Int Assoc Plant Taxonomy 2004b;53:919-23.

7. Hester AJ, Scogings PF, Trollope WS. Long-term impacts of goat browsing on bush-clump dynamics in a semi-arid subtropical savanna. Plant Ecol 2006;183:277-90.

8. Miller JS. Classification of Boraginaceae subfam. Ehretioideae : Resurrection of the genus Hilsenbergia Tausch ex Meisn. World 2003;25:151-89.

9. Forster PI. Ehretia grahamii (Boraginaceae): Notes on distribution, habitat, variation and conservation status. Queensland Herbarium $1995 ; 4: 451-2$

10. Gottschling M, Hilger HH. First fossil record of transfer cells in angiosperms. Am J Bot 2003;90:957-9.

11. Gurke M. Die Natürlichen Pflanzenfamilien. Vol. 4. Germany: W. Engelmann, Leipzig; 1893. p. 59-96.

12. Pimienta-Barrios E, Robles-Murguia C, Martinez-Chavez CC. Ecophysiological responses of native and exotic young trees to drought and rainfall. Rev Fitotecnia Mex 2012;35:15-20.

13. Retief E, Van Wyk AE. The genus Ehretia (Boraginaceae: Ehretioideae) In Southern Africa. Bothalia 2001;31:9-23.

14. Shu HK. Ehretia P. browne, Civ. nat. Hist. Jamaica 168. 1756. Flora of China. 1995;16:333-6.

15. Miller JS. A revision of the new world species of Ehretia (Boraginaceae). Ann Mo Bot Gard 1989;76:1050-76.

16. Scott PE, Martin RF. Avian consumers of Bursera, Ficus, and Ehretia fruits in Yucatán. Biotropica 1984;16:319-23.

17. Joshi R, Singh R. Feeding behaviour of wild Asian elephants (elephas maximus) in the Rajaji National Park. J Am Sci 2008;4:34-48.

18. Bakshi MP, Wadhwa M. Evaluation of forest tree leaves of semi-hilly arid region as livestock feed. Asian Aust J Anim Sci 2004;17:777-83.

19. Tefera S, Mlambo V, Dlamini BJ, Dlamini AM, Koralagama KD, Mould FL. Chemical composition and in vitro ruminal fermentation of common tree forages in the semi-arid rangelands of Swaziland. Anim Feed Sci Technol 2008;142:99-110.

20. Bandyopadhyay S, Kr MS. Wild edible plant of Koch Bihar District, West Bengal. Natl Prod Radiance 2009;8:64-72.

21. Mandal G, Joshi SP. Quantitative vegetation dynamics and invasion success of lantana camara from the tropical forests of doon valley. Int $\mathrm{J}$ Conserv Sci 2014b;5:511-26.

22. Rao BH, Rao PSP. Embryology of three species of Ehretia. Proc Indian Acad Sci (Plant Sci.) 1984;93:57-65.

23. Li L, Li MH, Xu LJ, Guo N, Wu-Lan T, Shi R, et al. Distribution of seven polyphenols in several medicinal plants of Boraginaceae in China. J Med Plants Res 2010;4:1216-21.

24. Jeruto P, Mutai C, C. L, O. G. Phytochemical constituents of some medicinal plants. JAnim Plant Sci 2011;9:1201-10.

25. Li L, Peng Y, Yao X, Xu L, Wulan T, Liu Y, et al. Chemical constituents and biological activities of plants from the genus Ehretia Linn. Chinese Herb Med 2010;2:106-11.

26. Jain S, Srivastava S. Dictionary of Ethnoveterinary Plants of India. Dictionary of Ethnoveterinary Plants of India. New Delhi: Deep Publications; 1999. p. 218.

27. Wang WT. Flora Reipublicae Popularis Sinicae. Beijing: Science Press; 1979.

28. Choudhury S, Sharma P, Choudhury MD, Sharma GD. Ethnomedicinal plants used by Chorei tribes of Southern Assam, North Eastern India. Asian Pac J Trop Dis 2012;2:141-7. 
29. Wang YC, Huang TL. Screening of anti-helicobacter pylori herbs deriving from Taiwanese folk medicinal plants. FEMS Immunol Med Microbiol 2005; 43:295-300

30. Torane RC, Kamble GS, Kale AA, Gadkari TV, Deshpande NR. Quantification of dioctyl phthalate from Ehretia laevis Roxb by HPTLC. J Chem Pharm Res 2011a;3:48-51.

31. Torane RC, Kamble GS, Gadkari TV, Tambe AS, Deshpande NR. GCMS study of nutritious leaves of Ehretia laevis. Int J ChemTech Res 2011;3:1589-91.

32. Sharma J, Gairola S, Sharma YP, Gaur RD. Ethnomedicinal plants used to treat skin diseases by Tharu community of district Udham Singh Nagar, Uttarakhand, India. J Ethnopharmacol 2014;158 Pt A:140-206.

33. Yamamura S, Simpol LR, Ozawa K, Ohtani K, Otsuka H, Kasai R, et al. Antiallergic dimeric prenylbenzoquinones from Ehretia microphylla. Phytochemistry 1995;39:105-10.

34. Iqbal K, Nawaz SA, Malik A, Riaz N, Mukhtar N, Mohammad P, Choudhary MI. Isolation and lipoxygenase-inhibition study of phenolic constituent from Ehretia obstifolia. Chem Biodiv 2005;2:104-11.

35. Ogundajo AL, Nnaemeka CO, Olawunmi RO, Ogunwande IA. Chemical Constituents of essential oil of Ehretia cymosa Thonn. Br J Appl Sci Technol 2016;14:1-6.

36. Sempombe J, Mugoyela V, Mihale MJ, Zacharia A, Ipagala P, Kilulya KF. Preliminary in vivo antitrypanosomal activity and cytotoxicity of Entada abyssinica, Securinega virosa and Ehretia amoena. East Central Afr J Pharm Sci 2014;17:37-43.

37. Yoshikawa K, Kageyama H, Arihara S. Phenolic glucosides and lignans from Ehretia ovalifolia. Phytochemistry 1995;39:659-64.

38. Li L, Xu LJ, He ZD, Yang QQ, Peng Y, Xiao PG. Chemical study on ethyl acetate portion of Ehretia thyrsiflora, Boraginaceae species of Ku-Ding-Cha. China J Chinese Mater Med 2008;17:2121-3.

39. Li L, Peng Y, Xu LJ, Li MH, Xiao PG. Flavonoid glycosides and phenolic acids from Ehretia thyrsiflora. Biochem Syst Ecol 2009a;36:915-8.

40. Khattab AM, Grace MH, El-Khrisy EA. ChemInform abstract: A new flavone derivative from Ehretia ovalifolia leaves. Pharmazie 2001;56:661-2

41. Suri OP, Jamwal RS, Suri KA, Atal CT. Ehretinine, a novel pyrrolizidine alkaloid from Ehretia aspera. Phytochemistry 1980;19:1273-4.

42. Li L, Studies on Quality Control of Small Leaves Ku-Ding-Cha and Preliminary Pharmacophylogeny on Boraginaceae Ku-Ding-Cha. Ph.D. Dissertion, Peking Union Medical College, Beijing; 2009

43. Dong M, Oda Y, Hirota M. (10E,12Z,15Z)-9-hydroxy-10,12,15octadecatrienoic acid methyl ester as an anti-inflammatory compound from Ehretia dicksonii. Biosci Biotechnol Biochem 2000;64:882-6.

44. Selvanayagam ZE, Gnanavendhan SG, Balakrishna K, Rao RB, Sivaraman J, Subramanian K, et al. Ehretianone, a novel quinonoid xanthene from Ehretia buxifolia with antisnake venom activity. J Natl Prod 1996;59:664-7.

45. Agarwal SK, Rastogi RP, Van Koningsveld H, Goubitz K, Olthof GJ. The molecular structure of 4a, 5, 8, 8a-tetrahydro-11,14-dimethoxy-7methyl-4a-(3-methyl-2-butenyl)-5,8a-O-benzeno-1,4-naphthoquinone. Tetrahedron 1980;36:1435-8.

46. Thapliyal PC, Yadav SK. A new naphthoquinone from aerial parts of Ehretia laevis. J Inst Chem India 2003;75:13-5.

47. Chien Y, Lin C, Chiang MY, Chang H, Liao C, Chen I, et al. Secondary metabolites from the root of Ehretia longiflora and their biological activities. Phytochemistry 2012;80:50-7.

48. Simpol LR, Otsuka H, Ohtani K, Kasai R, Yamasaki K. Nitrile glucosides and rosmarinic acid, the histamine inhibitor from Ehretia philippinensis. Phytochemistry 1994;36:91-5.

49. Dan S, Dan SS. Triterpenoids of the bark of Ehretia laevis. Fitoterapia 1982;53:51-2.

50. Li L, Tu YH, Xu LJ, Ma P, Peng Y, Wu QL, et al. Antioxidant activities and identification of the polyphenol characters by HPLC/UV/MS on Ehretia thyrsiflora. Natl Prod Res Dev 2009b;21:360-4.

51. Torane RC. In-vitro antioxidative activity of phenolic and flavonoid contents of leaves of medicinal plant-Ehretia laevis. Int J Pharm Biosci 2011;2:810-5.

52. Saad R, Asmani F, Saad M, Hussain M, Khan J, Kaleemullah M, et al. A new approach for predicting antioxidant property of herbal extracts. Int J Pharm Phytochem Res 2015;7:166-74

53. Saman Z, Dildar A, Hira B, Muhammad I. Evaluation of antioxidant activities of various solvent extracts of fruits and leaves of Ehretia serrata. Asian J Chem 2012;24:4345-435.

54. Sivasankar V, Revathi P, Parimelazhagan T. Evaluation of in vitro antioxidant activity in edible fruits of Ehretia laevis Roxb. Int J Pharm Bio Sci 2013;4:847-57
55. Juan FP, Sylvia PD, Mercedes GL, Julio M, Gabriela L, Francisco D. Physicochemical, nutritional and antioxidant characteristics of the fruit of Ehretia tinifolia. Rev Mex Biodiv 2012;83:273-80.

56. Palaniappan R, Senguttuvan J, Kandasamy P, Subramaniam P. In vitro antioxidant properties of the traditional medicinal plant species, Ehretia microphylla Lam. and Erythroxylon monogynum Roxb. Res J Pharm Biol Chem Sci 2014;5:247-52.

57. Jyothirmai N, Nagaraju B, Deepika MY, Kumar JN, Rani GS. Evaluation of anti-inflammatory and anti-bacterial activities of different solvent extracts of Ehretia laevis Roxb. J Pharm Sci Res 2016;8:715-20.

58. Rimando AM, Inoshiri S, Otsuka H, Kohda H, Yamasaki K, Padolina WG, et al. Screening for mast cell histamine release inhibitory activity of Philippine medicinal plants. Active constituent of Ehretia microphylla. Japanese J Pharmacog 1987;41:242-7.

59. Deshpande R, Kamath A, Chaturvedi S, Mutha MM, Shep S, Torane R, et al. Comparative evaluation of antimicrobial properties of different extracts of 'Ehretia laevis' against salivary microflora. Res J Pharm Biol Chem Sci 2014;5:489

60. Gumgumjee NM, Hajar AS. Antibacterial activities and gc-ms analysis of phytocomponents of Ehretia abyssinica R.Br. Ex Fresen. Int J Appl Biol Pharm Technol 2015;6:236-41

61. Demetrio LV, Jeannie IA, Juliana JM, Esperanza CC, Windell LR. Antibacterial activities of ethanol extracts of Philippine medicinal plants against multidrug-resistant bacteria. Asian Pac J Trop Biomed 2015;5:532-40.

62. Velappan S, Thangaraj P. Phytochemical constituents and antiarthritic activity of Ehretia laevis Roxb. J Food Biochem 2013;38:433-43.

63. Freiburghaus F, Ogwal EN, Nkunya MH, Kaminsky R, Brun R. In vitro antitrypanosomal activity of African plants used in traditional medicine in Uganda to treat sleeping sickness. Trop Med Int Health 1996; $1: 765-71$

64. Joshi B, Hendrickx S, Magar LB, Parajuli N, Dorny P, Maes L. In vitro antileishmanial and antimalarial activity of selected plants of Nepal. J Intercult Ethnopharmacol 2016;5:383-9.

65. Mohiuddin M, Arbain D, Islam AK, Rahman M, Ahmad MS, Ahmad MN. Electrochemical measurement of the antidiabetic potential of medicinal plants using multi-walled carbon nanotubes paste electrode. Russ J Electrochem 2015:51:368-75.

66. Venkata PK, Prameela RA, Pooja B, Anil KY. Phytochemical screening, spectroscpic characterisation and cardiotonic activity of aqueous extract from arieal parts of Carmona retusa (Vahl) masam on isolated frogs heart. Int J Pharm Chem 2016;6:231-6.

67. Shaoyong Y, Fan D, Ruinian L, Dan Z, Zhaoqiang H. A new species of Ehretia, Ehretia retroserrata in Nujiang County, Yunnan Province, China. Am J Plant Sci 2015;6:260-3.

68. Aarthi V, Anbu J, Ahamed KF, Anjana A, Velpandian V. Effect of Ehretia microphylla lamk on stimulation of reproductive function and ovarian folliculogenesis in rats. Int J Pharm Biosci 2012;3:273-80.

69. A.H., M., S., H., R., J., M., R. Some medicinal plants used in Bangladesh in traditional medicinal treatment of various forms of cancer. Planta Med 2009;75:1537-41.

70. Mageswari S, Karpagam S, Reddy GA. Evaluation of wound healing activity of the plant Carmona retusa (Vahl.) Masam., in mice. Int $\mathrm{J}$ Integr Sci Innov Technol 2015;4:1-4.

71. Quintana E, Saludez J, Batoon M, Generalao M. Agricultural production of selected medicinal plants: Propagation to postharvest handling. Philipp Counc Agric Resour Res Dev 1982;10:8-10

72. Chakraborty M, Bhattacharjee A. A Plants used as masticatories by the ethnic communities of Purulia District, West Bengal, India. J Econ Taxonomic Bot 2003;27:568-70

73. Shah A, Rahim S. Ethnomedicinal uses of plants for the treatment of malaria in Soon Valley, Khushab, Pakistan. J Ethnopharmacol 2017;200:84-106.

74. Airi S, Rawal R, Samant S, Dhar U. Treatments to improve germination of four multipurpose trees of central sub Himalaya. Seed Sci Technol 1998;26:347-54.

75. Gottschling M, Luebert F, Hilger HH, Miller JS. Molecular delimitations in the ehretiaceae (boraginales). Mol Phylogenet Evol 2014;72:1-6.

76. Dzib-Guerra W del C, Escalante-Erosa F, Garcia-Sosa K, Derbre S, Blanchard P, Richomme P, Pena-Rodriguez L. Anti-Advanced glycation end-product and free radical scavenging activity of plants from the yucatecan flora. Pharmacog Res 2016;8:276.

77. Thakre R, Bhutada S, Chouragade B, Khobragade P, Harne K. Unexplored wound healing property of Ehretia leavis Roxb. (Khandu chakka) plant. Int J Res Ayurveda Pharm 2016;7:54-7. 